\title{
Growth Performance and Intestinal Morphometric Features of Broiler Chickens Fed on Dietary Inclusion of Yellow Mealworm (Tenebrio Molitor), Larvae Powder
}

\author{
Shadi Sedgh-Gooya \\ Razi University \\ Mehran Torki ( $\nabla$ Torki@razi.ac.ir) \\ Razi University https://orcid.org/0000-0001-5660-0273 \\ Maryam Darbemamieh \\ Razi University \\ Hassan Khamisabadi \\ Institute of Applied Scientific Education of Jahad-e Agricultural \\ Alireza Abdolmohamadi \\ Razi University
}

\section{Research Article}

Keywords: Broiler chickens, Growth performance, Intestinal morphology, Tenebrio molitor larvae meal

Posted Date: November 30th, 2021

DOI: https://doi.org/10.21203/rs.3.rs-1079968/v1

License: @ (1) This work is licensed under a Creative Commons Attribution 4.0 International License. Read Full License 


\section{Abstract}

Climate change and the lack of conventional feed ingredients have made edible insects a highly nutritious alternative to feed production. The use of insects as food may help solve socio-economic and environmental problems around the world and be in line with the United Nations Sustainable Development Goals. In this study, the growth performance and intestinal morphology of broiler chickens were evaluated under the influence of adding different levels of Tenebrio molitorlarvae meal (TM meal) to their diets. One hundred eighty day-old broiler chickens were divided into 3 treatments and 5 replications ( 12 chickens/pen). The experimental diets included a control diet and treatments containing 2.5 and $5 \%$ TM meal, which were fed to birds in the starter (0-10 days) and grower (11-25 days) stages, and during the final period (26-42 days), all birds were fed a regular finisher diet. The results showed that the diet containing TM meal had no remarkable effect on the mortality rate and feed intake (FI) of broilers $(P>0.05)$. In the period of starter, the addition of $2.5 \%$ TM meal to broilers diet increased body weight gain (BWG) than the control group ( $P £ 0.05)$. Also, the use of $2.5 \%$ TM meal in the starter period showed a significant effect on reducing the feed conversion ratio (FCR) compared to the birds fed by the control diet $(P £ 0.05)$. Besides, the height of the villus, the depth of the crypt, and the ratio of them were not altered among the different treatments $(P>0.05)$. Overall, it can be concluded that TM meal could improve growth performance in the starter period, and had no negative effects on broilers' performance and intestinal morphology in all the periods of the experiment.

\section{Introduction}

Today, world food production is facing the challenges of population growth, climate change, and competition for the use of highquality agricultural land, while experts believe that healthy food has the least environmental risks and the least efficiency of nonrenewable resources such as water (FAO 2011). One of the main problems of the poultry industry is the preparation of feeds that contain all the essential nutrients for the rapid growth of poultry in a short time. The nutritional requirement of monogastric species includes high quality and quantity of protein in the diet. It helps maintain and repair animal tissues as well as their proper growth and development (Bondari and Sheppard 1981). The main sources of protein in broilers diet are soybean meal and fish meal, which both are associated with several problems such as short supply in the future due to the lack of water for cultivation, rising prices, dependence on imports, and competition with human food (Van Huis and Oonincx 2017). So, many current livestock systems need to be changed and innovated to meet current and future demand for livestock products. In this regard, research on new ingredients (especially those rich in protein), is necessary. The insect protein content is about 40 to $60 \%$ dry matter and fat content is 30 to $40 \%$ dry matter, and also the amino acids and essential fatty acids in insects are similar to sources such as fish meal and soybean meal that are commonly used in poultry diets. These characteristics make insects an alternative to protein sources in poultry diets (Makkar et al. 2014). Moreover, minerals such as calcium, iron, potassium, magnesium, phosphorus, and zinc and vitamins such as niacin, vitamin B12, thiamine, and riboflavin are abundant in larvae (Spranghers et al. 2017; Akhtar and Isman 2018). The use of insects as a food has also some environmental advantages such as high feed conversion efficiency, shorter life cycle, less influenced by environmental calamities, lower emission of greenhouse gases and ammonia, and less water and land to grow (Ballitoc and Sun 2013; Makkar et al. 2014). Of the various types of insects, special attention has been paid to the mealworm. Mealworms, Tenebrio molitor L. (Coleoptera: Tenebrionidae), are the brown worm-like larvae of darkling beetles and can be found almost everywhere on the planet and they prefer warm, dark, and damp places like under decaying leaves (Makkar et al. 2014). Larvae have different nutritional values depending on their species and stage of development and contain significant amounts of protein, fat, and essential vitamins or minerals, and amino acids (Rumpled and Schlüter 2013). Moreover, mealworm is an excellent source of nitrogen. Nitrogen in mealworms is present in the form of D-acetyl glucosamine, a sugar amino acid that forms chitin, which is indigestible to poultry but is fermented in the large intestine by microorganisms (Sanchez-Muros et al. 2014; Selaledi et al. 2019). Van Huis (2013) observed that by adding mealworms to broilers' diet, the usage of antibiotics was reduced because the diet contained about $3 \%$ chitin, which increased the population of benefit intestinal microbiota such as lactobacillus and reduced the intestinal harmful bacteria such as Salmonella and Escherichia coli populations. The safety of mealworms was investigated in different aspects including antibiotics, toxins, pesticides, and heavy metals (Han et al. 2014; Adámková et al. 2017; EFSA NDA Panel 2021). The results of these experiments showed that compared to other types of insects, mealworms had the lowest risk in terms of safety. In general, mealworms that grow in closed systems and do not feed on organic matter or animal waste in nature are less susceptible to pathogenic microbes or toxic compounds (EFSA NDA Panel 2021).

Studies showed that gastrointestinal characteristics affect the efficiency of dietary protein utilization (Swatson et al. 2002). In particular, among the main indicators of growth, health, and function of the intestine is the microscopic structure of the small intestine in terms of villi height and crypt depth, which affects the digestion and absorption of nutrients (Wang and Peng 2008). Changes in protein source and diet structure have been suggested to have a negative impact on the morphology of broilers in terms of reducing the 
height of villi and increasing the depth of the crypt (Qaisrani et al. 2014). Although it has been shown that intestinal morphology is affected by changes in poultry diets (Laudadio et al. 2012; Qaisrani et al. 2014), there are not many studies on the effect of TM meal on the morphometric traits of the intestine. So, this study aimed to determine the growth performance, and intestine morphology of broilers fed on a TM meal included diet.

\section{Material And Methods}

\section{Broiler chickens and management}

The experiment was done with 180 one-day-old broilers (Arbor Acres with an average weight of $41 \mathrm{~g}$ ). The birds were randomly assigned to three treatments with five replicates (12 chickens/ pen). The pens were about $1.50 \mathrm{~m}$ wide and $1.50 \mathrm{~m}$ long, in which there was a feeder, a nipple drinker, and chips of wood as a bed. Vaccination schedule and management tips such as room temperature and humidity were according to Aviagen (2014) standard breeding practices In the first 7 days of the broiler breeding period, 23 hours of light and 1 hour of darkness were provided, and then from 7 days until the end of the breeding period, the birds were under 18 hours of light and 6 hours of darkness.

\section{Diets}

Experimental treatments included zero levels of TM meal as a control group and the levels of 2.5 and $5 \%$ of TM meal as a substitute for the dietary protein source, which was fed in the starter (1-10 days) and grower (11-25 days) periods. The usual finisher diet was provided to all treatments until the end of the period (26-42 days). The broilers had free access to water and food throughout the trial and rations were provided in the mash forms. Diet adjustment was performed using the recommendations of Aviagen (2014) as well as the (NRC 1994), and energy and protein were equal for all treatments in each trial period (crude protein, $\mathrm{CP}=237.5 \mathrm{~g} / \mathrm{kg}$, metabolizable energy, $\mathrm{ME}=3023 \mathrm{Kcal} / \mathrm{Kg}$ at starter phase and $\mathrm{CP}=210 \mathrm{~g} / \mathrm{kg}, \mathrm{ME}=3155 \mathrm{Kcal} / \mathrm{Kg}$ at grower phase, Table 1). In this study, the amounts of apparent metabolizable energy (AME) obtained from De Marco et al. (2015) experiments on broilers were used.

\section{Preparation of mealworm}

Mealworms were grown on the wheat bran substrate within 100 plastic boxes of $40 \times 27 \times 11 \mathrm{~cm}$, through the reproduction of adult beetles. Fruits such as carrots and potatoes were used to supply water to the mealworms. After the larvae reached their maximum size, they were separated from the manure by sieving. After 48 hours, mealworms were placed in the freezer to be killed and then placed in an oven at $60^{\circ} \mathrm{C}$ for 20 hours to dry. The samples were then analyzed to determine the amount of crude protein, fat, crude fiber, ash, calcium, and phosphorus content (AOAC 2005) (Table 2). The amino acid composition of TM meal was determined using highperformance liquid chromatography (HPLC) by the method of Madrid et al. (2013). Besides, by the following formula (ash-free ADF (\%) - ADIP (\%)), the chitin content was calculated (Marono et al. 2015) (Table 2).

\section{Growth performance}

On the first day of the experiment and also on days 10,25, and 42 the broilers were weighted to determine BWG, periodically. To measure $\mathrm{Fl}$, the feed was weighed daily and the feed residual was measured at the end of days 10,25 , and 42 . Then, through the data obtained from BWG and Fl, the FCR was calculated. Mortality was monitored during the experimental period and used to calculate mortality rates and correct data.

\section{Histomorphological investigations}

From the middle part of jejunum and ileum of broilers at 25 days of age, samples about $3 \mathrm{~cm}$ long were prepared and washed with phosphate buffer (10 birds each treatment). The samples were then placed in 10\% formalin buffer solution for 24 hours, after which their solution was changed and kept in formalin buffer until testing. Tissues are typically embedded in paraffin wax blocks, cut to a thickness of $5 \mu \mathrm{m}$, mounted on glass slides, and stained with Haematoxylin \& Eosin (Biasato et al. 2018). Investigations included the height of the villus, the depth of the crypt, and the ratio of the villus height to the crypt depth. The height of the villi from the tips of the villi to the intersection of the villi-crypt (a) and crypt depth from the base of the villus to the submucosa (b) was measured using light microscopy (Nikon Eclipse 80i, Nikon Co., Tokyo, Japan) (Fig.1). The number of villi and crypts measured for each tissue averaged 5.

\section{Statistical analysis}


To analyze the data, the statistical software of SAS 9.4 with GLM procedure (General Linear Model) was used (SAS Institute 2015). The statistical model of the experiment is as follows:

$Y_{i j}=\mu+T_{i}+e_{i j}$ where $Y$ is the dependent variable, $\mu$ is the overall mean, $T$ is the fixed effect of treatments ( $i=C$, TM2.5 or TM5 diet), and $\mathrm{e}$ is the random error. Data were also corrected for the effect of gender (male and female). A comparison between means was done by Duncan's multiple range tests (Duncan 1955). Orthogonal comparisons were performed to evaluate group comparisons of treatments as well as linear and quadratic responses on SAS software.

\section{Results}

\section{Chemical composition and Growth performance}

Table 2 shows the chemical composition and amino acid profile of TM meal. According to our result, TM meal contained about 970.2 $\mathrm{g} / \mathrm{kg}$ dry matter, $508.1 \mathrm{~g} / \mathrm{kg} \mathrm{CP}, 280.3 \mathrm{~g} / \mathrm{kg}$ ether extract, $69.9 \mathrm{~g} / \mathrm{kg}$ ash, $75.3 \mathrm{~g} / \mathrm{kg}$ crude fiber, and $56.0 \mathrm{~g} / \mathrm{kg}$ chitin. Moreover, calcium and phosphorous content in the TM meal were 35.0 and $68.0 \mathrm{~g} / \mathrm{kg}$, respectively.

The health status of the chickens was checked throughout the rearing period. According to the results of this experiment, no remarkable difference was observed between the experimental treatments regarding the mortality rate of broiler chickens $(P>0.05)$. Moreover, according to Table 3 , the dietary treatments had no remarkable impact on Fl of broilers in all the experimental periods ( $P$ $>0.05)$. In addition, broilers fed by a diet containing TM meal had a greater BWG than the control group in the starter period (1-10 days; $P £ 0.05)$. The greatest BWG belongs to the diet containing $2.5 \%$ of TM meal, which was significantly different from the control group (186.27 vs. $169.25 \mathrm{~g}, P £ 0.05$; Table 3). Besides, a quadratic response was found among treatments on BWG in the period of starter ( $P$ $=0.040$ ). According to our result, no remarkable impact of experimental diets was seen on the BWG in the other periods of the recent trial $(P>0.05)$. In most of the studied periods, there was no significant effect between treatments in terms of FCR, except for the starter period, which according to orthogonal comparisons, FCR decreased with 2.5\% TM meal than the control group $(P=0.044$; Table 3).

\section{Histomorphology}

The intestinal morphometric measurements under the effect of different levels of TM meals are reported in Table 4. According to the result, villi height, crypt depth, and the ratio of them were not changed under the influence of experimental diets $(P>0.05)$.

\section{Discussion}

The nutrient composition of the TM meal provided in our experiment was in the range accounted in other studies (Hong et al. 2020) (Table 2). The protein content of TM meal ( $538.1 \mathrm{~g} / \mathrm{kg}$ in a recent study) was close to the protein content of common feed components such as soybean meal (440-480 g/kg) and fish meal $(500-600 \mathrm{~g} / \mathrm{kg})$ used in the poultry industry (Nascimento Filho et al. 2021). But, TM meal contains a greater amount of ether extract $(280.3 \mathrm{~g} / \mathrm{kg})$ than soybean meal $(216.0 \mathrm{~g} / \mathrm{kg})$ and fish meal $(117.0 \mathrm{~g} / \mathrm{kg})$ (Nascimento Filho et al. 2016). In addition, the data in Table 2 showed that TM meal had the same or higher levels of most essential amino acids than substances such as soybean meal and fish meal (Hong et al. 2020). These results show that TM meal is a good quality substance that is used in the formulation of diets to prepare the chicken's amino acid needs. The induced or natural conditions included in the production or processing of TM meals could be the reason for the variety in the nutrient composition that was observed in different studies (Makkar et al. 2014).

Since there was no remarkable difference between the control diet and diets containing TM meal on FI of broilers, it can be concluded that TM meal, especially at low inclusion levels used in the present study, was palatable for broilers, and it would not negatively affect their FI. According to the literature, increasing insect levels in poultry diets reduces $\mathrm{FI}$ due to the imbalance of nutrients and amino acids in the diet (Moula and Detilleux 2019). Also, high levels of chitin in the skeleton of insects were introduced as other effective factors in reducing $\mathrm{Fl}$, by increasing the levels of insects in poultry diets due to its low digestibility (Moula and Detilleux 2019). In our study, low levels of TM meal (2.5 and 5\%) in the diet of broilers were used. The amount of chitin in TM meal was about $5.6 \%$ per $\mathrm{kg}$ of dry matter (Table 2), and all diets were equal in terms of energy and protein in all periods (respectively for the starter: $3023 \mathrm{kcal} / \mathrm{kg}, 237.5 \mathrm{~g} / \mathrm{kg}$; grower: $3155 \mathrm{kcal} / \mathrm{kg}, 210 \mathrm{~g} / \mathrm{kg}$; finisher: $3203 \mathrm{kcal} / \mathrm{kg}, 190 \mathrm{~g} / \mathrm{kg}$; Table 1). So, no negative effect on Fl was observed, and all diets had the same performance in this regard. Ballitoc and Sun (2013) investigated the effect of using the levels of $0,0.5,1,2$, and $10 \%$ of TM meal on Fl of broilers at weeks 2 to 5 . It was shown that at the end of the rearing period, the highest Fl after the control groups was related to the treatment containing 1\% TM meal, and the lowest one was related to the treatment containing $10 \%$ TM meal. According 
to the results of this experiment, Elahi et al. (2020) stated that up to $8 \%$ of TM meal could be used in the diet of broilers without any remarkable effect on FI.

The BWG was greater in broilers fed by TM meal than the control diet at the starter period; however, in other periods of trial, no significant difference was observed between treatments regarding BWG. Insect meal has been shown to be more similar to animal sources of protein than plant origin protein (Hong et al. 2020). Cromwell (1998) showed that animal protein sources have higher bioavailability than plant-based protein sources. Also, another reason for the higher efficiency of nutrients in the body of birds fed with TM meal can be attributed to the prebiotic effect of chitin in the skeleton of insects. According to Bovera et al. (2015), chitin is a linear polysaccharide chain of $\mathrm{N}$-acetyl-D-glucosamine units that are linked by a $\beta$ (1-4) bond and have low digestibility in poultry, so it can play a prebiotic role. One of the important functions of prebiotics in the body is to reduce the population of harmful microorganisms in the intestine and improve gastrointestinal health (Sedghgooya et al. 2021). Reducing the population of harmful bacteria can affect the digestion and absorption of nutrients in the intestine by improving gastrointestinal health. In addition, there are reports that the use of prebiotics in broiler diets has increased intestinal digestibility of nutrients (Sahane 2001). Elahi et al. (2020) investigated the influence of using levels of $0,2,4$, and $8 \%$ of dried or $10.48 \%$ of live mealworm in broiler diets on their growth performance. According to their results, containing $4 \%$ of TM meal in the diet had the potential to increase the body weight of broilers, especially during the starter period of the experiment. In contrast, Biasato et al. (2016), and Bovera et al. (2015) reported that TM meal did not change the BWG of broilers compared to the control diet.

In this study, the decrease in FCR in the starter period was due to the increase in the weight of broilers by consuming similar amounts of feed, which shows the higher nutrient efficiency of TM meals compared to control diets in the broilers. One reason for this better performance can be attributed to the prebiotic role of chitin. Bovera et al. (2016) reported that replacing soybean meal with TM meal reduced the apparent ileal digestibility coefficients of dry and organic matter by $2 \%$ in broilers fed a diet containing TM meal compared to broilers fed soybean meal. TM meal also had lower protein digestibility coefficients of $8.2 \%$. Interestingly, the reduction in nutrient digestibility observed in the group containing TM meal did not affect growth performance, and broilers from both experimental groups had the same slaughter weight. Besides, broilers fed TM meal showed an improved FCR compared to the control group (Bovera et al. 2016). According to the findings of Ballitoc and Sun (2013), when TM meal was added from 0 to $10 \%$ in the diet of broilers, a decreasing trend in FCR was observed. Similar to the results of a recent experiment, Elahi et al. (2020) reported that the addition of $4 \%$ TM meal to broiler diets improved the FCR in the starter period. Ramos-Elorduy et al. (2002) reported that adding 5 to $10 \%$ of TM meal as an alternative to soybean meal and vegetable oils had no remarkable impact on the FCR of fast-growing broilers. In the experiment of Biasato et al. (2016), the replacement of corn gluten meal with TM meal (7.5\%) had no significant effect on broilers FCR. In addition, Benzertis et al. (2019) reported that adding low levels of TM meal (0.2\% and $0.3 \%)$ to broiler diets did not affect their FCR.

According to our result, villus height, crypt depth, and the ratio of villus height to crypt depth of the jejunum and ileum were not affected by the experimental diets $(P>0.05)$, thus showing no negative effects on nutrient metabolism, yield and animal health as a result of the replacement of TM meal in the diet of broilers. Similar results are reported in a study by Biasato et al. (2016), who found that the inclusion of 7.5\% TM meal in the diet of broilers did not have a significant effect on the intestinal morphometric indices. Studies showed that gastrointestinal characteristics affect the efficiency of protein utilization (Swatson et al. 2002), which is considered as a regulator of growth and production performance (Laudadio et al. 2012). Measurement of intestinal morphology, especially villi length and crypt depth are important factors in determining intestinal health, function and development, which affects the metabolism of nutrients (Wang and Peng 2008). Crypts are very important because they are the areas where new cells are formed, and villus is important because of the vital role they play in digesting and absorbing nutrients (Swatson et al. 2002). The ideal morphology of the gut seems to be determined by a high villus and shallow crypts. Longer villus is generally associated with increased levels of total absorption, and better performance of digestive enzymes, and greater nutrient transport (Laudadio et al. 2012). Besides, the shallow depth of the crypt makes the villi live longer (Oliveira et al. 2008), which in turn helps other tissues to grow by reducing energy consumption for this process (Miles et al. 2006). Conversely, poor digestion and absorption of nutrients and consequently the weak performance of animals can be caused by reducing the length of the villi and increasing the depth of the crypts. Changes in protein source and diet structure have been shown to have a negative impact on the morphology of the small intestine in broilers in terms of decreasing villus height and increasing crypt depth (Qaisrani et al. 2014). According to Biasato et al. (2018), the use of high levels of TM meal (15\%) in poultry diets altered their intestinal morphology, so they suggested that low levels of TM meal were better and should be preferred. Also in confirmation of this hypothesis, Biasato et al. (2016) showed that no change was seen in the morphometric indices of chickens fed 7.5\% TM meal. Besides, in the present study, the low levels of TM meal were used and no negative effects on morphometric indices were observed. 


\section{Conclusion}

The use of TM meal in broilers diet can lead to improved BWG and efficient use of feed in the starter period (1-10 days). Among the different levels of TM meal used in the recent experiment regarding broiler performance, the best result was obtained with a level of $2.5 \%$. The height of the villus, the depth of the crypt depth, and villus height to crypt depth ratio were not influenced by dietary treatments. So it could be concluded that TM meal was safe and had no negative effects on broilers.

\section{Declarations}

\section{Acknowledgement}

The authors appreciate Razi University for financially supporting the current study.

\section{Funding}

No funding was received to assist with the preparation of this manuscript.

\section{Data Availability}

The datasets generated during and/or analysed during the current study are not publicly available are available from the corresponding author on reasonable request.

\section{Conflict of interest}

The authors have no conflict of interest to be declared.

\section{Ethics approval code}

Ethical approval was waived by the local Ethics Committee of Razi University in view of the retrospective nature of the study and all the procedures being performed were part of the routine care. The license for keeping and treating broilers, issued by the Animal Ethics Committee of Razi University, is \# 79 at 10/23/2019.

\section{References}

Adámková A, Adámek M, Mlček J, Borkovcová M, Bednářová M, Kouřimská L, Skácel J, Vítová E (2017) Welfare of the mealworm (Tenebrio molitor) breeding with regard to nutrition value and food safety. Potravinarstvo Slovak Journal of Food Sciences, 11: 460465 .

Akhtar Y, Isman M B (2018) Insects as an alternative protein source. In Proteins in Food Processing. Edited by Rickey YY. Wood head Publishing Series in Food Science, Technology and Nutrition, 263-288.

Association of Official Analytical Chemistry (AOAC) (2005) Official methods of analysis (18th ed.). Washington, DC: AOAC.

Aviagen (2014) Arbor Acres broiler management handbook. Broiler performance objectives. Retrieved from http://en.avi-agen.com.

Ballitoc DA, Sun S (2013) Ground yellow mealworms (TenebriomolitorL.) feed supplementation improves growth performance and carcass yield characteristics in broilers. Open Science Repository Agriculture. e23050425,doi:10.7392/openaccess.23050425

Benzertiha A, Kierończyk B, Kołodziejski P, Pruszyńska-Oszmałek E, Rawski M, Józefiak D, Józefiak A (2019) Tenebrio molitor and Zophobas morio full-fat meals as functional feed additives affect broiler chickens' growth performance and immune system traits. Poultry Science, 99:196-206.

Biasato I, De Marco M, Rotolo L, Renna M, Dabbou S, Capucchio MT, Biasibetti E, Tarantola M, Costa P, Gai F, Pozzo L, Dezzutto D, Bergagna S, Gasco L, Schiavone A (2016) Effects of dietary Tenebriomolitor meal inclusion in free-range chickens. Journal of Animal Physiology and Animal Nutrition, 100:1104-1112. 
Biasato I, Gasco L, De Marco M, Renna M, Rotolo L, Dabbou S, Capucchio MT, Biasibetti E, Tarantola M, Bianchi L, Cavallarin F, Gai L, Pozzo D, Dezzutto S, Bergagna L, Schiavone A (2018) Yellow mealworm larvae (Tenebriomolitor) inclusion in diets for male broiler chickens: effects on growth performance, gut morphology, and histological findings. Poultry Science, 97(2): 540-548.

Bondari K, Sheppard DC (1981) Soldier fly larvae as feed in commercial fish production. Aqua-culture, 24:103-109.

Bovera F, Loponte R, Marono S, Piccolo G, Parisi G, laconisi V, Gasco L, Nizza A (2016) Use of Tenebrio molitor larvae meal as protein source in broiler diet: effect on growth performance, nutrient digestibility, and carcass and meat traits. Journal of Animal Science, 94:639-647.

Bovera F, Piccolo G, Gasco L, Marono S, Loponte R, Vassalotti G, Nizza A (2015) Yellow mealworm larvae (Tenebriomolitor, L.) as a possible alternative to soybean meal in broiler diets. British Poultry Science, 56:569-575.

Cromwell GL (1998) Feeding swine. In: Livestock Feeds and Feeding (4th ed). Prentice-Hall, Upper Saddle River, NJ, USA.

De Marco M, Martínez S, Hernandez F, Madrid J, Gai F, Rotolo L, Belforti M, Bergero D, Katz H, Dabbou S, Kovitvadhi A (2015) Nutritional value of two insect larval meals (Tenebrio molitor and Hermetia illucens) for broiler chickens: Apparent nutrient digestibility, apparent ileal amino acid digestibility and apparent metabolizable energy. Animal Feed Science and Technology, 209:211-218.

Duncan DB (1955) Multiple range and multiple F tests. Biometrics, 11, 1-42.

EFSA Panel on Nutrition, Novel Foods and Food Allergens (NDA), Turck, D., Castenmiller, J., De Henauw, S., Hirsch-Ernst, K.I., Kearney, J., Maciuk, A., Mangelsdorf, I., McArdle, H.J., Naska, A., Pelaez, C (2021) Safety of dried yellow mealworm (Tenebrio molitor larva) as a novel food pursuant to Regulation (EU) 2015/2283. EFSA Journal, 19(1): 06343.

Elahi U, Wang J, Ma Y, Wu S, Wu J, Qi G, Zhang H (2020) Evaluation of yellow mealworm meal as a protein feedstuff in the diet of broiler chicks. Animals, 10(2):224.

FAO (2011) Food and Agriculture Organization, the state of the world's land and water resources for food and agriculture, Managing systems at risk, Food and Agriculture Organization of the United Nations, Rome and Earthscan, London.

Han SR, Yun EY, Kim JY, Hwang JS, Jeong EJ, Moon KS (2014) Evaluation of genotoxicity and 28-day oral dose toxicity on freeze-dried powder of Tenebrio molitor larvae (Yellow mealworm). Toxicological Research, 30:121-130.

Hong J, Han T, Kim YY (2020) Mealworm (Tenebrio molitor Larvae) as an Alternative Protein Source for Monogastric Animal: A Review. Animals, 10(11):2068.

Laudadio V, Passantino L, Perillo A, Lopresti G, Passantino A, Khan RU, Tufarelli V, (2012) Productive performance and histological features of intestinal mucosa of broiler chickens fed different dietary protein levels. Poultry Science, 91:265-70.

Madrid J, Martínez S, López C, Orengo J, López MJ, Hernández F (2013) Effects of low protein diets on growth performance, carcass traits and ammonia emission of barrows and gilts. Animal Production Science, 53(2):146-53.

Makkar HP, Tran G, Heuzé V, Ankers P (2014) State-of-the-art on use of insects as animal feed. Animal Feed Science and Technology, 197:1-33.

Marono S, Piccolo G, Loponte R, Di Meo C, Attia YA, Nizza A, Bovera F (2015) In vitro crude protein digestibility of Tenebrio molitorand Hermetia illucens insect meals and its correlation with chemical composition traits. Italian Journal of Animal Science, 14:338-349.

Miles RD, Butcher GD, Henry PR, Littell RC (2006) Effect of antibiotic growth promoters on broiler performance, intestinal growth parameters, and quantitative morphology. Poultry Science, 85:476-485.

Moula N, Detilleux J (2019) A meta-analysis of the effects of insects in feed on poultry growth performances. Animals, 9(5):201.

Nascimento Filho MA, Pereira RT, Oliveira ABS, Suckeveris D, Junior AB, Soares CAP, Menten, JFM (2021) Nutritional value of Tenebrio molitor larvae meal for broiler chickens: Metabolizable energy and standardized ileal amino acid digestibility. Journal of Applied

Page $7 / 13$ 
Poultry Research, 30(1):100102.

NRC (1994) National Research Council, Nutrient Requirements of Poultry, 9th revised ed. National Academy Press, Washington, DC, USA.

Oliveira MC, Rodrigues EA, Marques RH, Gravena RA, Guandolini GC, Moraes VM (2008) Performance and morphology of intestinal mucosa of broilers fed mannan-oligosaccharides and enzymes. Arquivo Brasileiro de Medicina Veterinária e Zootecnia, 60(2):442-448.

Qaisrani SN, Moquet PC, Van Krimpen MM, Kwakkel RP, Verstegen MW, Hendriks WH (2014) Protein source and dietary structure influence growth performance, gut morphology, and hindgut fermentation characteristics in broilers. Poultry Science, 93:3053-3064.

Ramos-Elorduy J, González EA, Hernández AR, Pino JM (2002) Use of Tenebrio molitor (Coleoptera :Tenebrionidae) to recycle organic wastes and as feed for broiler chickens. Journal of Economic Entomology, 95:214-220.

Rumpold BA, Schlüter OK (2013) Nutritional composition and safety aspects of edible insects. Molecular nutrition \& food research, 57(5):802-823.

Sahane MS (2001) Mannanoligosaccharides in poultry nutrition: Mechanism and benefits. In Proc. Altech's 17thAnnual Symp. Eds. Lyons, TP \& Jacques, KA, Nottingham University Press 65-77.

Sanchez-Muros MJ, Barroso FG, Manzano-Agugliaro F (2014) Insect meal as renewable source of food for animal feeding: a review. Journal of Cleaner Production, 65:16-27.

SAS Institute (2015) SAS user's guide. Version 9.4. Cary, NC: SAS Inst. Inc.USA.

Sedgh-Gooya S, Torki M, Darbemamieh M, Khamisabadi H, Karimi Torshizi MA, Abdolmohamadi A (2021) Yellow mealworm, Tenebrio molitor (Col: Tenebrionidae), larvae powder as dietary protein sources for broiler chickens: Effects on growth performance, carcass traits, selected intestinal microbiota and blood parameters. Journal of Animal Physiology and Animal Nutrition, 105(1):119-128.

Selaledi L, Mbajiorgu CA, Mabelebele M (2019) The use of yellow mealworm (T. molitor) as alternative source of protein in poultry diets: A review. Tropical Animal Health and Production, 52:7-16.

Spranghers T, Ottoboni M, Klootwijk C, Ovyn A, Deboosere S, De Meulenaer B, Michiels J, Eeckhout M, De Clercq P, De Smet S (2017) Nutritional composition of black soldier fly (Hermetia illucens) prepupae reared on different organic waste substrates. Journal of the Science of Food and Agriculture, 97:2594-2600.

Swatson HK, Gous R, lji PA, Zarrinkalam R (2005) Effect of dietary protein level, amino acid balance, and feeding level on growth, gastrointestinal tract, and mucosal structure of the small intestine in broiler chickens. Animal Research, 51:501-15.

van Huis A (2013) Potential of insects as food and feed in assuring food security. Annual review of entomology, 58:563-583.

Van Huis A, Oonincx DG (2017) The environmental sustainability of insects as food and feed. A review. Agronomy for Sustainable Development, 37(5):1-14.

Wang JX, Peng KM (2008) Developmental morphology of the small intestine of African ostrich chicks. Poultry science, 87:2629-35.

\section{Tables}

Table 1. Ingredients and nutritional level of the diets 


\begin{tabular}{|c|c|c|c|c|c|c|c|}
\hline \multirow[b]{2}{*}{ Ingredients (g/kg) } & \multicolumn{3}{|c|}{$\begin{array}{l}\text { Starter period } \\
\text { (days 1-10) }\end{array}$} & \multicolumn{3}{|c|}{$\begin{array}{l}\text { Grower period } \\
\text { (days 11-25) }\end{array}$} & \multirow[t]{2}{*}{$\begin{array}{l}\text { Finisher period } \\
\text { (days 26-42) }\end{array}$} \\
\hline & C & TM2.5 & TM5 & C & TM2.5 & TM5 & \\
\hline Corn & 475.9 & 457.7 & 441.1 & 574.7 & 558.0 & 541.4 & 637.5 \\
\hline Fish meal & 15.5 & - & - & 49.0 & 49.0 & 49.0 & 48.0 \\
\hline Soybean meal & 416.8 & 404.9 & 367.1 & 290.9 & 253.0 & 214.9 & 233.4 \\
\hline TM larvae meal & - & 25 & 50 & - & 25 & 50 & - \\
\hline Wheat bran & - & 19.0 & 48.7 & - & 29.9 & 59.7 & - \\
\hline Oil & 50.6 & 50.6 & 50.6 & 51.2 & 51.2 & 51.2 & 47.3 \\
\hline Dicalcium phosphate & 16.0 & 15.0 & 14.3 & 16.9 & 16.1 & 15.4 & 16.9 \\
\hline Calcium carbonate & 9.6 & 11.5 & 12.0 & 5.2 & 5.7 & 6.1 & 4.4 \\
\hline Sodium chloride & 3.8 & 4.0 & 3.9 & 3.3 & 3.2 & 3.2 & 3.3 \\
\hline Vitamin mixture $^{\mathrm{a}}$ & 2.5 & 2.5 & 2.5 & 2.5 & 2.5 & 2.5 & 2.5 \\
\hline Mineral mixture ${ }^{b}$ & 2.5 & 2.5 & 2.5 & 2.5 & 2.5 & 2.5 & 2.5 \\
\hline Threonine & 2 & 2 & 2 & 0.9 & 0.9 & 0.9 & 1.2 \\
\hline L-lysine & 1.4 & 2 & 2.3 & 0.6 & 0.9 & 1.1 & 0.9 \\
\hline DL-methionine & 3.4 & 3.3 & 3.0 & 2.3 & 2.2 & 2.1 & 2.2 \\
\hline \multicolumn{8}{|c|}{ Calculated composition $(\mathrm{g} / \mathrm{kg})^{\mathrm{C}}$} \\
\hline Energy (Kcal/Kg) & 3023 & 3023 & 3023 & 3155 & 3155 & 3155 & 3203 \\
\hline $\mathrm{CP}$ & 237.5 & 237.5 & 237.5 & 210 & 210 & 210 & 190 \\
\hline $\mathrm{EE}$ & 67.7 & 72.2 & 77.7 & 72.6 & 78.1 & 83.6 & 71.0 \\
\hline CF & 39.8 & 42.2 & 44.3 & 33.4 & 35.4 & 37.4 & 30.8 \\
\hline $\mathrm{Na}$ & 1.8 & 1.8 & 1.8 & 1.8 & 1.8 & 1.8 & 1.8 \\
\hline Lysine & 14.3 & 14.3 & 14.3 & 12.2 & 12.2 & 12.2 & 11.0 \\
\hline Methionine & 7 & 6.8 & 6.7 & 6 & 6 & 6 & 5.6 \\
\hline Calcium & 9.1 & 9.1 & 9.1 & 8.5 & 8.5 & 8.5 & 8 \\
\hline Available phosphorus & 4.5 & 4.5 & 4.5 & 4.4 & 4.4 & 4.4 & 4.3 \\
\hline
\end{tabular}

Three dietary treatments: $\mathrm{C}=$ control; TM2.5 = 2.5\% inclusion level of Tenebrio molitor, TM5 = 5\% inclusion level

aVitamin premix provided per kilogram of diet: 12,500 IU vitamin A (from retinyl acetate), 3,700 IU cholecalciferol, 40 IU vitamin E (from DL- a-tocopheryl acetate), $0.03 \mathrm{mg}$ vitamin B12, $6.4 \mathrm{mg}$ riboflavin, $55 \mathrm{mg}$ niacin (as nicotin amide), $30 \mathrm{mg}$ pantothenic acid (as calcium pantothenate), $3.5 \mathrm{mg}$ menadione (from menadione dimethyl-pyrimidinol), $1.2 \mathrm{mg}$ folic acid, $3 \mathrm{mg}$ thiamine, $7.5 \mathrm{mg}$ pyridoxine, $0.3 \mathrm{mg}$ biotin, $560 \mathrm{mg}$ choline (as choline chloride 60\%), and $80 \mathrm{mg}$ ethoxyquin.

${ }^{b}$ Mineral premix provided per kilogram of diet: 80 mg Mn (from MnSO4•H2O), 70 mg Zn (from ZnO), 50 mg Fe (from FeSO4•7H2O), 8 $\mathrm{mg}$

$\mathrm{Cu}$ (from CuSO4•5H2O), $1.5 \mathrm{mg} \mathrm{I} \mathrm{(from} \mathrm{Ca} \mathrm{(IO3)2•H2O),} \mathrm{and} 0.35 \mathrm{mg}$ Se (from Na selenite). 
${ }^{\mathrm{C}} \mathrm{CP}$, crude protein; $\mathrm{EE}$, ether extract; $\mathrm{CF}$,crude fiber

Table 2. Nutrient and amino acids composition of the yellow mealworm

\begin{tabular}{|ll|}
\hline Items & Tenebrio molitor meal \\
\hline Analyzed composition $(\mathrm{g} / \mathrm{kg})^{\mathrm{a}}$ & \\
\hline DM & 970.2 \\
\hline CP & 538.1 \\
\hline EE & 280.3 \\
\hline Ash & 69.9 \\
\hline CF & 75.3 \\
\hline Chitin & 56.0 \\
\hline Calcium & 35.0 \\
\hline Phosphorus & 68.0 \\
\hline Amino Acids $(\%)$ & \\
\hline Methionine & \\
\hline Cysteine & 3.667 \\
\hline Methionine+ Cysteine & 0.434 \\
\hline Lysine & 1.101 \\
\hline Arginine & 2.748 \\
\hline Threonine & 3.230 \\
\hline Leucine & 2.591 \\
\hline Isoleucine & 1.899 \\
\hline Valine & 3.931 \\
\hline Histidine & 2.796 \\
\hline Phenylalanine & \\
\hline Glycine & \\
\hline Serine & \\
\hline Proline & \\
\hline Alanine & \\
\hline
\end{tabular}

${ }^{a} \mathrm{DM}$, dry matter; $\mathrm{CP}$, crude protein; $\mathrm{EE}$, ether extract; $\mathrm{CF}$,crude fiber

Table 3. Growth performance of the broiler chicks fed on the TM meal diet 


\begin{tabular}{|c|c|c|c|c|c|c|c|c|c|c|c|c|}
\hline \multirow[t]{2}{*}{ Items $^{\mathrm{a}}$} & \multicolumn{5}{|c|}{ BWG (g) } & \multicolumn{4}{|l|}{$\mathrm{FI}(\mathrm{g})$} & \multicolumn{3}{|c|}{ FCR $(\mathrm{g} / \mathrm{g})$} \\
\hline & $1-10 d$ & $\begin{array}{l}11- \\
25 d\end{array}$ & $26-42 d$ & $1-42 d$ & $1-10 d$ & $11-25 d$ & $26-42 d$ & $1-42 d$ & $1-10 d$ & $\begin{array}{l}11- \\
25 d\end{array}$ & $\begin{array}{l}26- \\
42 d\end{array}$ & $1-42 d$ \\
\hline C & $169.2 b$ & 668.5 & 1343.1 & 2260.6 & 222.6 & 1186.4 & 2739.0 & 4283.7 & 1.32 & 1.79 & 2.04 & 1.90 \\
\hline TM2.5 & $186.2 a$ & 633.9 & 1392.8 & 2287.7 & 231.8 & 1225.7 & 2786.1 & 4381.2 & 1.25 & 1.93 & 2.00 & 1.92 \\
\hline TM5 & 178.2ab & 643.8 & 1341.4 & 2242.5 & 227.8 & 1190.0 & 2736.9 & 4295.3 & 1.28 & 1.86 & 2.04 & 1.92 \\
\hline $\mathrm{SEM}^{\mathrm{b}}$ & 3.014 & 11.93 & 18.14 & 21.75 & 2.30 & 9.95 & 21.47 & 25.66 & 0.01 & 0.03 & 0.02 & 0.01 \\
\hline P-value & 0.05 & 0.50 & 0.45 & 0.72 & 0.28 & 0.21 & 0.60 & 0.25 & 0.12 & 0.22 & 0.80 & 0.78 \\
\hline \multicolumn{13}{|c|}{ Orthogonal contrasts (P-value) } \\
\hline C vs TM & 0.034 & 0.272 & 0.548 & 0.928 & 0.156 & 0.306 & 0.641 & 0.318 & 0.068 & 0.140 & 0.712 & 0.498 \\
\hline $\begin{array}{l}\text { C vs } \\
\text { TM2.5 }\end{array}$ & 0.018 & 0.268 & 0.290 & 0.637 & 0.119 & 0.115 & 0.404 & 0.133 & 0.044 & 0.088 & 0.562 & 0.538 \\
\hline C vs TM5 & 0.177 & 0.422 & 0.970 & 0.751 & 0.364 & 0.879 & 0.970 & 0.850 & 0.247 & 0.397 & 0.953 & 0.575 \\
\hline $\begin{array}{l}\text { TM2.5 vs } \\
\text { TM5 }\end{array}$ & 0.225 & 0.746 & 0.274 & 0.434 & 0.477 & 0.149 & 0.384 & 0.181 & 0.322 & 0.347 & 0.601 & 0.955 \\
\hline Linear & 0.177 & 0.422 & 0.970 & 0.751 & 0.364 & 0.879 & 0.970 & 0.850 & 0.247 & 0.397 & 0.953 & 0.575 \\
\hline Quadratic & 0.040 & 0.405 & 0.218 & 0.470 & 0.189 & 0.086 & 0.327 & 0.105 & 0.082 & 0.128 & 0.526 & 0.696 \\
\hline
\end{tabular}

Three dietary treatments: $\mathrm{C}=$ control; TM2.5 = 2.5\% inclusion level of Tenebrio molitor, $\mathrm{TM} 5=5 \%$ inclusion level

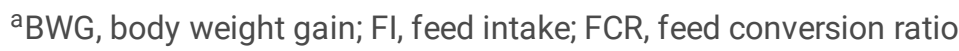
Means with different superscripts in columns differ significantly $(P £ 0.05)$.

${ }^{b}$ Standard error of the mean.

Table 4. Intestinal morphometric measurements of broilers fed on the TM meal diets 
Ileum

\begin{tabular}{|c|c|c|c|c|c|c|}
\hline & $\begin{array}{l}\text { Villus height } \\
(\mu \mathrm{m})\end{array}$ & $\begin{array}{l}\text { Crypt depth } \\
(\mu \mathrm{m})\end{array}$ & $\begin{array}{l}\text { Villus } \\
\text { height/crypt } \\
\text { depth ratio }\end{array}$ & $\begin{array}{l}\text { Villus height } \\
(\mu \mathrm{m})\end{array}$ & $\begin{array}{l}\text { Crypt depth } \\
(\mu \mathrm{m})\end{array}$ & $\begin{array}{l}\text { Villus } \\
\text { height/crypt } \\
\text { depth ratio }\end{array}$ \\
\hline C & 1399.16 & 279.16 & 5.02 & 1326.33 & 280.33 & 4.77 \\
\hline TM2.5 & 1434.50 & 287.66 & 4.99 & 1397.50 & 284.50 & 4.93 \\
\hline TM5 & 1544.33 & 292.50 & 5.29 & 1380.83 & 277.83 & 4.98 \\
\hline SEM $^{a}$ & 32.50 & 5.09 & 0.09 & 26.42 & 4.99 & 0.11 \\
\hline \multirow[t]{2}{*}{ P-value } & 0.17 & 0.58 & 0.40 & 0.54 & 0.87 & 0.76 \\
\hline & & & \multicolumn{3}{|c|}{ Orthogonal contrasts (P-value) } & \\
\hline C vs TM & 0.191 & 0.341 & 0.567 & 0.290 & 0.941 & 0.481 \\
\hline C vs TM2.5 & 0.650 & 0.517 & 0.907 & 0.299 & 0.751 & 0.599 \\
\hline C vs TM5 & 0.076 & 0.314 & 0.275 & 0.423 & 0.849 & 0.486 \\
\hline $\begin{array}{l}\text { TM2.5 vs } \\
\text { TM5 }\end{array}$ & 0.170 & 0.711 & 0.230 & 0.804 & 0.613 & 0.861 \\
\hline Linear & 0.076 & 0.314 & 0.275 & 0.423 & 0.849 & 0.486 \\
\hline Quadratic & 0.581 & 0.871 & 0.442 & 0.455 & 0.635 & 0.838 \\
\hline
\end{tabular}

Three dietary treatments: $\mathrm{C}=$ control; $\mathrm{TM} 2.5=2.5 \%$ inclusion level of Tenebrio molitor, $\mathrm{TM} 5=5 \%$ inclusion level Means with different superscripts in columns differ significantly $(P £ 0.05)$.

astandard error of the mean.

\section{Figures}

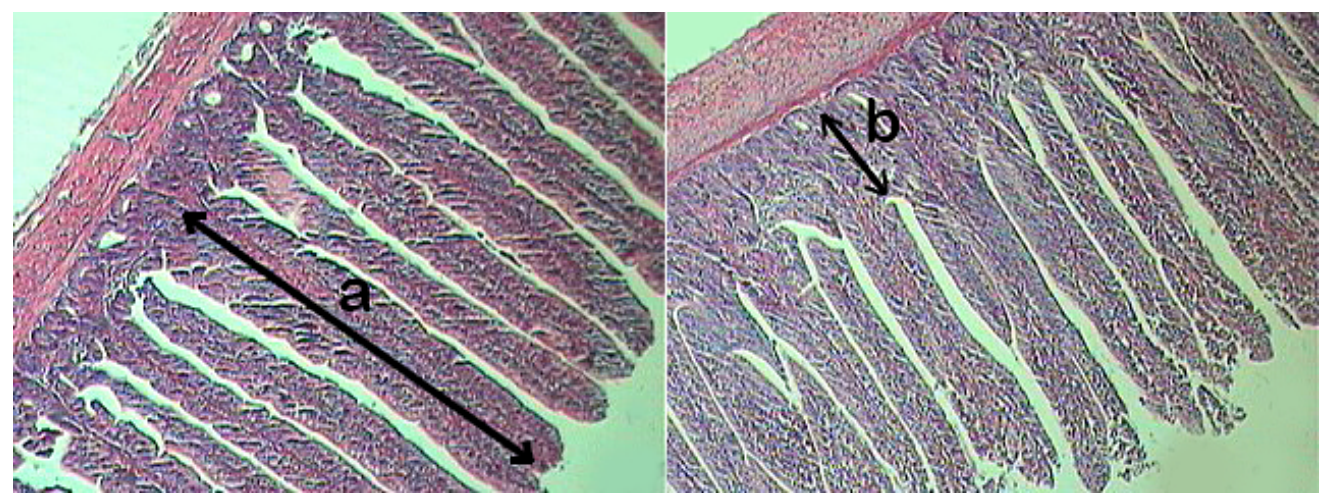

\section{Figure 1}

Morphometric measurements of the villus height (a) and the crypt depth (b) in the jejunum and ileum segment

\section{Supplementary Files}

This is a list of supplementary files associated with this preprint. Click to download. 
- ARRIVEComplianceQuestionnaire.pdf

Page 13/13 